\title{
A Need Analysis in English Material for XI Grade of Beauty Program at SMK N 2 Singaraja
}

\author{
N.K. Wedhanti ${ }^{1{ }^{*}}$ D.A Eka Agustini ${ }^{1}$ I Nym Pasek Hadi Saputra ${ }^{1}$ I P N Wage \\ Myartawan $^{1}$ \\ ${ }^{1}$ English Language Education Study Program, Universitas Pendidikan Ganesha, Singaraja, Indonesia \\ *Corresponding author. Email: karina.wedhanti@undiksha.ac.id
}

\begin{abstract}
The purpose of this study was to investigate the English material and assess the appropriateness of English teaching material based on ESP principles. The qualitative descriptive method was used in this study. The eleventh grade beauty program students at SMK N 2 Singaraja were the subjects of this study. Questionnaires and document checklists were used as data collection tools. The findings revealed that the students required English-specific materials and Englishspecific skills in the tourism field, particularly in the beauty spa. Furthermore, according to the document checklist, the English teaching material in the beauty program was not appropriate with the ESP concepts because the data revealed that the teaching material was too general and did not pertain to the students' field. As a result, the beauty students hoped that the school could design an ESP program to help them improve their competence in beauty spa activities.
\end{abstract}

Keywords: ESP, Learning need, Need analysis.

\section{INTRODUCTION}

Determine what English skills students need to learn before designing a course with an educational objective. In line with [1] NA is a procedure for gathering information to serve as a foundation for creating curriculum that meets the needs of students]. According to [2] the roles of need analysis are not only to gather data but also to provide direction in the development of a course or the creation of educational materials for students. An approach known as a "need analysis" is employed to gather data on the English language skills of potential students.

According to [3] there are two types of needs to consider when analyzing learners' needs: learners' needs and learning needs. The first is learners' needs, which examines what learners must do with English in the target situation. Learners' needs are divided into three categories: necessities, deficiencies, and desires. The term "necessities" refers to what students must know in order to communicate effectively in English in a specific context. What the students lack is concerning. haven't known and the difficulty of learning English, whereas wants are the perspective and hope of each learner's individual needs in learning English. Learning needs are the second distinction in need analysis. [3] stated that learning needs refer to what students must do in order to learn English. It is a way of thinking about how to organize and create engaging activities in the learning process.

The implementation of need analysis had function to support the understanding of students in learning process because the material based on students' need. One of the material that can be implemented this need analysis is English for Specific Purpose (ESP). According to [3] ESP refers to an approach to language teaching in which all content and method are based on the learners' reason for learning a language. Based on this statement, the structure of English for Specific Purpose material is based on the students' need toward one field that wants to master by the students. So, the role of need analysis is to support the process of analyzing and creating the material based on the students' field toward English for specific purpose. In Indonesia, the application of need analysis toward English for specific purpose tends to applicate for vocational high school (SMK). The English material for vocational high school focused on students work for the future. According to [4], teaching English in vocational schools is a process in education that prepares students for future work. Therefore, the implementation of need analysis is needed to build the teaching material for English specific purpose that has an effect to master 
the English based on the students' field in vocational high school. In order to teach English in a vocational school, the teacher must establish several points in the ESP program, including a teaching guideline, a syllabus, and appropriate materials to aid in the learning process.

Based on preliminary observations, SMK N 2 Singaraja implemented the revised 2013 curriculum. The revised 2013 English curriculum in vocational high school (SMK) and high school (SMA) had equal content consisting of basic competencies/core competencies (KD/ KI) and subject content [5]. According to preliminary observations, the students did not receive English for a specific purpose for their major. It made it difficult for the student to communicate with the guest when they were going to train in a specific area. It occurred as a result of the teacher's use of material that was too general for the students. In the meantime, students required English for a specific purpose.

According to the above explanation, the first step was for the researcher to conduct a need analysis in English material at a vocational high school in Singaraja. This study was carried out to investigate the needs of the beauty program in English material and to analyze the appropriateness of teaching English material for beauty program students, particularly those in the eleventh grade. The subject was chosen in the eleventh grade because they had learned four English skills since the tenth grade: speaking, listening, reading, and writing. Aside from that, they have difficulty communicating in English. This study was unique because it was conducted in eleventh grade beauty program students at SMK N 2 Singaraja. The location was chosen because the school implemented a curriculum that was equivalent to that of a public senior high school (SMA). Furthermore, there was no English for ESP students. As a result, it provided novelty in terms of setting. Furthermore, this study was unique in terms of data collection, as it was done through an online platform that used a Google form. The findings of this study can be used to suggest to English teachers that they create specific English materials for beauty program students.

\section{METHOD}

The research used descriptive qualitative approach. Descriptive qualitative research is research that concerns describing, interpreting situation, and conditions that used to explain in report research [6]. In this research, qualitative research was used to investigate the eleventhgrade students of beauty program needs in English material and analyze the appropriateness of English teaching material for eleventh grade students of beauty program based on ESP principles.

The setting of this study was SMK N 2 Singaraja, which is located at Jl. Srikandi, No 9, Babakan, Baktiseraga. The setting was chosen because of the vocational high school implemented same syllabus with public high school. Besides, based on the preobservation, the students in SMK N 2 Singaraja stated that, they didn't get ESP course for their programs. Moreover, the vocational high school is one of vocational school that has a good accreditation which the school become a national standard educational institution that prepares students to enter the specific work field. All the eleventh-grade students of beauty program were the subject of this research.

In collecting the data, the researcher used two instruments, namely; questionnaire and document checklist. The researcher used questionnaire to gain the data about the beauty program students' needs in English material. Document checklist used to analyze investigate the appropriateness of English teaching material for eleventh grade students of beauty program based on ESP principles by [3].

\section{RESULT AND DISCUSSION}

\subsection{The students of beauty program needs in English learning material}

From the result of the questionnaire, $44.8 \%$ students of eleventh beauty program stated that they learned English because they purposed be able to communicate in English. $49.3 \%$ student of beauty program needed learning English because English is very important in tourism industry. Therefore, when it was asked the main reason $82.1 \%$ students stated that, they needed English in order to communicate with foreigner during training. Based on the data, it can be concluded that the necessities of beauty program was English which was taught to the students specifically about English for tourism. According to the result of the data of students' questionnaire, it showed that 58.2\% students had problem in learning English. Based on [3], the lack focused on the needs that appeared from the learners' deficiency to a certain condition. This aspect was needed to identify what the learners already know and what the learners do not know. From the questionnaire, students were dominant stated that the most difficult skill in English was speaking. When the researcher asked the reason why students were difficult to learn English, they revealed that, they could not understand English learning material. It indicated that the material was too hard for the students in beauty program or the students could not follow the learning process that made to have less vocabulary.

[3] stated that the wants are the kind of needs that the learner desire. It is possible that the learners' views about their needs different from other related parties' views (course designer or teacher). This different view was also called as "wants". Then, $64.2 \%$ students" speaking skill as the most needed skill in learning English. They wanted to improve that skill because the skill is important in the 
beauty major. It indicated that speaking skill related to their job in tourism industry or salon later on.

[3] stated that, learning needs focuses on the way to learn English for their specific purposes. It means learners need knowledge and ability in order to perform to the required degree of competence in target situation. The result of the questionnaire, $32.8 \%$ students stated that they wanted to use internet as the main sources in learning English. They chose internet because they collected the information about English material. It was related toward students' need of speaking activity. $44.8 \%$ students chose speaking activity in the form dialogue and did practice in pair. Meanwhile in listening activity, $56.7 \%$ students argued that they need authentic material such as song, film, and news to support the listening activity. Then, $38.8 \%$ students preferred writing simple sentences or paragraph for writing activity. In reading activity, $44.8 \%$ students needed simple text that related with their program and easy to find in daily life. From the resulted it showed that, students desired to simple material in learning English and they needed material that related with their major which was used for training and future job.

Every student had different specific time when they want to learn English. There was no concreate answer of the students because they had different time to learn English. From the students' answer, most of students said that, they preferred study English in the morning. Furthermore, related to the place for study, students preferred to learn in class rather than in the library, language lab, or outside classroom.

The most students were $82.3 \%$ students stated that the purpose of learning English was to enable communicate in English in the marketing activities. $82.3 \%$ students chose English speaking skill as the skill which wanted to be increased. Speaking was not only the desire for students but also $67 \%$ students stated that the skill was the lack for them. These results were found based on the students' answer in questionnaire.

Based on the explanation above, it revealed that the eleventh grade of beauty program of SMK N 2 Singaraja needed specific English for their program. The result of the students' need showed that the reason they learned English was enable to communicate effectively using English with foreigner. Most of them stated that students needed to learn English because English was very important in tourism sector, especially in spa and beauty salon. Thus, they wanted to improve speaking skill in learning English in order to function effectively in target situation.

\subsection{The Appropriateness of English Teaching Material for Eleventh Grade Students of Beauty Program}

\subsubsection{Provide a stimulus in learning}

According to [3] there are six principles of teaching material in ESP. The first principle of ESP was providing a stimulus in learning, it means that the material were expected to give positive effect for the students in order to encourage students' motivation in learning English. By giving fun and interesting text in learning material, the students gained knowledge and they would be enjoying follow the teaching and learning process. Based on document analysis result, the teaching material which has been used by the teacher to teach could not provide stimulus in learning at vocational high school. Based on analysis of English teacher lesson plan, the teaching material that was used by teacher to teach could not be able to provide stimulus in learning at Vocational high school. There was no interesting text and enjoyable activities which appropriate with students' field of study. Furthermore, the teaching material was not built up from students' existing knowledge because the teaching material was valid sources without doing a need analysis. In the previous research by [7] also found the same thing because those points in indicator did not full fill the appropriate of ESP course. In other word, the text that given was not suitable with the students' field study. The result of document analysis can be seen in table 1 .

\subsubsection{Help organize teaching and learning process The second principle of ESP concerned for}

Organizing teaching and learning process. In this indicator, teacher had to create a good material in order to organize the teaching and learning process. It was supported by [3] said that teaching material must be a way for students to achieve learning goals. Therefore, the role of teacher was strong and able to

Build the best teaching material for students. In this research also discussed about the how the value of teacher's teaching material. Based on the result of document analysis, there was no point that related with the principle of ESP. the illustration in teaching material was monotonous; it means that the teacher used same illustration in each meeting. The result can be seen at the table 2 
Table 1. The Result of Provide A Stimulus in Learning

\begin{tabular}{|c|c|c|c|c|}
\hline Indicator & Item checklist & Yes & No & Notes \\
\hline $\begin{array}{l}\text { Provide a } \\
\text { stimulus in } \\
\text { learning }\end{array}$ & $\begin{array}{l}\text { 1. The teaching material consists of engaging } \\
\text { text that is relevant to the students' field of } \\
\text { study.'Teaching material is built up from } \\
\text { students' existing knowledge } \\
\text { 2. Teaching material provide enjoyable activities } \\
\text { which engage the students' think capacity (ex: } \\
\text { activities should be considered for } \\
\text { intermediate level) } \\
\text { 3. The teaching material is based on the } \\
\text { students' ability to learn (it takes into account } \\
\text { the students' level). } \\
\text { Teaching material can give warminteraction } \\
\text { between students and teacher in the } \\
\text { classroom (ex: students and teachercan show } \\
\text { their ideas each other). }\end{array}$ & (ㅇ) & $\begin{array}{l}\text { H } \\
\text { () }\end{array}$ & $\begin{array}{l}\text { There was not appropriate } \\
\text { with students' field } \\
\text { The teaching material was } \\
\text { taken from valid sources } \\
\text { without doing need analysis } \\
\text { The activity was not suitable } \\
\text { with students thinking capacity. } \\
\text { It did not consider students' } \\
\text { level in learning } \\
\text { There was a friendly exchange } \\
\text { between the students and the } \\
\text { teacher. }\end{array}$ \\
\hline
\end{tabular}

Table 2. The Result of Help Organize Teaching and Learning Process

\begin{tabular}{|c|c|c|c|c|}
\hline Indicator & Item checklist & Yes & No & Notes \\
\hline $\begin{array}{l}\text { Help to } \\
\text { organize } \\
\text { teaching } \\
\text { and } \\
\text { learning } \\
\text { process }\end{array}$ & $\begin{array}{l}\text { 6. Teaching material refers to objectives of } \\
\text { learning (ex. if objectives of learning ask } \\
\text { students understanding about procedure } \\
\text { text, the text which is given is procedure text) } \\
\text { 7. Teaching material shows explanation of } \\
\text { language focus (ex: tenses of text or generic } \\
\text { structure of the text) } \boldsymbol{} \\
\text { 8. Teaching material should have variety oftext } \\
\text { for each meeting } \\
\text { 9. Teaching material should avoid using same } \\
\text { illustration for each meeting } \\
\text { 10. Teaching material should have different types } \\
\text { and number task for each meeting }\end{array}$ & () & & $\begin{array}{l}\text { There is explanation of genre } \\
\text { structure } \\
\text { It was fulfilled in teaching } \\
\text { material } \\
\text { The illustration in teaching } \\
\text { material was monotonous. } \\
\text { It could be acceptable }\end{array}$ \\
\hline
\end{tabular}

\subsubsection{Embody view of nature of language}

The third principle was to embody view of the nature of language. This part emphasized the teacher expected to hold on the pure language in creating a teaching material. From the result of data document analysis, the teaching material was not fulfill all of the points in indicator such as: brainstorming based on students' background, teaching material should consider students' skill in understanding material, and teaching material provided more attention for items that important for student. In this case, the teaching material in beauty program could not help the students to communicate naturally in specific work field. The result of document analysis can be seen in tabel 3 . 
Table 3. The Result of Embody View of Nature of Language

\begin{tabular}{|c|c|c|c|c|}
\hline Indicator & Item checklist & Yes & $\mathrm{No}$ & Notes \\
\hline $\begin{array}{l}\text { Embody a } \\
\text { view of nature } \\
\text { oflanguage } \\
\text { learning }\end{array}$ & $\begin{array}{l}\text { 11. Brainstorming based on students'background. } \\
\text { 12. Teaching material should consider students' skill in } \\
\text { understanding material which is given. (text, } \\
\text { dialogue, and so on) } \\
\text { 13. Teaching material gives more attention for items } \\
\text { that important to students. (ex: explanation about } \\
\text { metaphor or term that relate to field study) }\end{array}$ & & $\begin{array}{l}\text { (2) } \\
\text { () } \\
\text { (0) }\end{array}$ & $\begin{array}{l}\text { Teaching material } \\
\text { gave difficult brain } \\
\text { storming forstudents. } \\
\text { It was not found in } \\
\text { teaching } \\
\text { material. } \\
\text { There were not special } \\
\text { expectations in learning } \\
\text { material. }\end{array}$ \\
\hline
\end{tabular}

Table 4. The Result of Provide Nature of Learning Task

\begin{tabular}{|c|c|c|c|c|}
\hline Indicator & Item checklist & Yes & No & Notes \\
\hline $\begin{array}{l}\text { Provide } \\
\text { nature of } \\
\text { learning } \\
\text { task }\end{array}$ & $\begin{array}{l}\text { 14. The teaching materials are created with } \\
\text { different types of students' knowledge levels } \\
\text { in mind. (which is neither too easy nor too } \\
\text { difficult nor too far away) } \\
\text { 15. Teaching materials should be backed up by } \\
\text { real-life examples. } \\
\text { 16. Teaching material applies repetition in } \\
\text { practicing or task } \\
\text { 17. Teaching material should be simpler in order } \\
\text { to easier to understood by the learners (ex: } \\
\text { avoid unfamiliarvocabularies) }\end{array}$ & () & () & $\begin{array}{l}\text { It was not consider. } \\
\text { Exist. } \\
\text { Exist. } \\
\text { There were many unfamiliar } \\
\text { words in the text \& video. It } \\
\text { makes the students bored. }\end{array}$ \\
\hline
\end{tabular}

\subsubsection{Provide nature of learning task}

The fourth principles of ESP should provide nature of language assignment. In this indicator, the teacher must consider the students' level knowledge. Teacher should not only give an assignment, but also gave a clear example for the student in order to make the students understand to finish the assignment. Based on document analysis there were many unfamiliar words in learning material. It made students had difficulty to comprehend the learning material. The result of document analysis can be seen in table 4 .

\subsubsection{Broadening the teacher's knowledge}

The fifth principle of ESP was about broadening the teachers' knowledge. In this principle, there were several points that should exist in the teaching material of ESP, those are: teaching material must be attractive, teacher to be more creative in teaching, it should enrich teachers' insight toward ESP, then teaching material should expect teacher to use new technique in teaching learning process. In this case, the materials were expected to increase the teachers' knowledge not only focused on the learners. In fact, there was point could not reach the principles of teaching material for ESP. The teaching material had not enriched teacher' insight toward ESP, it 
means that the teaching material was not created for ESP.

In [7] all of each point in this indicator was not found in

Table 5. The Result of Broadening The Teacher's Knowledge

\begin{tabular}{|c|c|c|c|c|}
\hline Indicator & Item checklist & Yes & No & Notes \\
\hline \multirow{2}{*}{$\begin{array}{l}\text { Broadening } \\
\text { the teachers' } \\
\text { knowledge }\end{array}$} & $\begin{array}{l}\text { 18. Teaching material must be attracting teacher } \\
\text { to be more creative in teaching }\end{array}$ & () & & It can be acceptable. \\
\hline & $\begin{array}{l}\text { 19. Teaching material should enrich teachers' } \\
\text { insight toward ESP } \\
\text { 20. Teaching material expect teacher to use new } \\
\text { technique in teaching learning process }\end{array}$ & ()) & () & $\begin{array}{l}\text { It could not acceptable because } \\
\text { teaching material wasnot } \\
\text { created to ESP. } \\
\text { Strategy \& technique were } \\
\text { available in lesson plan. }\end{array}$ \\
\hline
\end{tabular}

Table 6. The Result of Provide Correct and Appropriate Language Use

\begin{tabular}{|c|c|c|c|c|}
\hline Indicator & Item checklist & Yes & No & Notes \\
\hline $\begin{array}{l}\text { Provide } \\
\text { correct and } \\
\text { appropriate } \\
\text { language } \\
\text { use }\end{array}$ & $\begin{array}{l}\text { 21. Teaching material expect to language } \\
\text { practice than language teaching } \\
\text { 22. Teaching material is designed from nature } \\
\text { communication in students' workplace. } \\
\text { 23. Practice in language teaching is suited with } \\
\text { students' workplace demand. } \\
\text { 24. Teaching task is based on students' } \\
\text { communication needs in their field study }\end{array}$ & & () & $\begin{array}{l}\text { More expected to language } \\
\text { teaching rather than language } \\
\text { practice. } \\
\text { It was not found in teaching } \\
\text { material. } \\
\text { It was not exist in teaching } \\
\text { material. } \\
\text { It was not found. }\end{array}$ \\
\hline
\end{tabular}

teacher syllabus and lesson plan in SMK N 2 Sijunjung. The result of document analysis can be seen in table 5 .

\subsubsection{Provide correct and appropriate language use}

The last principle of teaching material for ESP from [3] was about provided the correct and appropriate language use. From result of document analysis, all of each point was not reached the indicators in teaching material. Thus, the teaching material in syllabus and lesson plan at SMK N 2 Singaraja was expected to language teaching rather than language practice. It was not designed from nature communication in students' field. In addition, the assignment was not based on students' communication needs in their field study. The result of document analysis can be seen in table 6 .
Based on explanation above, it was indicate that the teaching material was too general for beauty students. There was no specific language use for beauty students. Furthermore, there was long gap between the students' field study and the learning material. Therefore, it revealed that the teaching material didn't meet with the students' goal in learning English.

\section{CONCLUSIONS}

Based on result of the research, it can be concluded that the eleventh grade of beauty students needed more specific English material in tourism field especially in beauty spa. It was supported by the result of questionnaire which showed $49.3 \%$ students stated that, the reason why they need learn English because English was very important in tourism sector and $82.1 \%$ students revealed that they need English during training to enable for communicating with foreigner. Besides, $64.2 \%$ of 
beauty students chose speaking skill as the important skill that they wanted to increase due to the most of beauty activities used speaking skills such as offering kinds of spa or haircut model. In addition, the researcher also did document analysis which the document checklist as the instrument. Based on the document analysis, the researcher could be concluded that the English teaching material in beauty program was not appropriate with the ESP concept because the data showed that the teaching material was too general and did not close to the students' field. There was no specific English for students in beauty program class.

\section{REFERENCES}

[1] H. Holec, Autonomy and Foreign Language Learning. Oxford/New York: Pergamon Press, 1981.

[2] Y. Khoshhal, "The Role of Teaching Materials in the ESP Course: A Case of Business English (Finance and Economics).," J. Humanist. Soc. Stud., vol. 9 , no. 1, p. 85, 2018.

[3] T. Hutchinson and A. Water, E Book English for Specific Purpose A Learning Centred Aproach Tom 1991.octet-stream. 1987.

[4] B. H. C. Khosiyono, "Topic-Based Esp Materials for Vocational School," Prominent, vol. 1, no. 1, pp. 4-11, 2018, doi: 10.24176/pro.v1i1.2486.

[5] Kemdikbud, Kurikulum 2013 Kompetensi Dasar SMK/MA. Jakarta: Kementrian Pendidikan dan Kebudayaan, 2013.

[6] B. Hancock, "An Introduction to Qualitative Research Authors," Qual. Res., vol. 4th, p. 504, 2009, doi: 10.1109/TVCG.2007.70541.

[7] O. Ronaldo, "Teaching Material for English Subject in Vocational High School," Teach. Mater. English Subj. Vocat. High Sch., pp. 170- 179, 2016. 